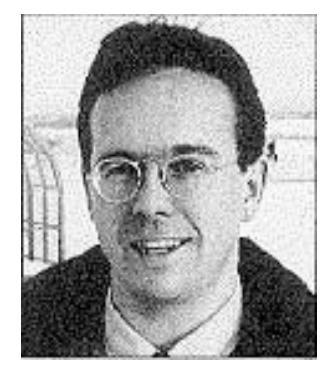

- Juha Suoranta

\title{
Parisuhde biovallannäyttämönä
}
" ...on epäilyttävää edes sanomattomasti väittää, ettei työn ulkopuolella, elämän muilla alueilla, kodissa, lähipiirissä, arjessa, voisi tapahtua kasvamista. Juuri niissä voi oppia paljon enemmän enemmästä ja tärkeämpää tärkeämmästä; niissä voi etsiä kohtaa aktiiviselle levolle, josta kaikki uutta luova syntyy."

Peter Jarvis on etenkin meillä noussut viime vuosina aikuiskasvatuksen teoretisoinnin keskeiseksi auktoriteetiksi. Erityisesti hänen käsityksensä oppimisesta myöhäismodernissa - oppimisen paradokseista - ovat tulleet tutuiksi tämän lehden sivuilta. Jarvisin ansioksi on sanottava, ettei hän jää leijumaan teorian utuun, vaan kiitettävästi tuo ideansa postmodernin yleisistä sfääreistä koskemaan aikuisten elämismaailmaa ja aikuisten sosiaalista oppimista. Tämä selkeyttäminen antaa mahdollisuuden myös ajatusten kritiikkiin aivan toisella tavalla kuin pitäydyttäessä postmodernin tavoittamattomissa yläkehissä. Seuraavassa tahdon problematisoida yhden yksityiskohdan Jarvisin kehittelystä ja osoittaa suunnan, josta sitä olisi mahdollisuus kehittää teoreettisesti eteenpäin.

\section{Mekanisoitu parisuhde}

Kysymys on erilleen kasvamisesta, jota Jarvis (1993; 1997) käyttää esimerkkinä havainnollistamaan oppimisen sosiaalisia merkityksiä ja paradokseja. Esimerkin alkutilanteessa paris- kunta jakaa yhteisen elämäntyylin. Toinen osapuoli saa uuden, vaativan työpaikan ja toinen pysyy paikallaan. Vanhassa työssään pysyvä ja vanhaa mutenkin toistava oppii Jarvisin mukaan vähemmän kuin toinen, joka joutuu uusien oppimishaasteiden eteen. Tästä alkaa kasvaminen erilleen.

Jarvis ei kuitenkaan vie kysymystään teoreettisesti riittävän pitkälle, vaan pitäytyy avioerotrendien ja niistä sikiävien huoltajuus- ja eettisten ongelmien sosiaalipoliittisissa ulottuvuuksissa. Hänen esimerkkinsä esittää ilmiön ybteiskunnallisena ongelmana, johon tulisi löytyä käytännöllinen ratkaisu. Näin Jarvis määrittelee parisuhteen dynamiikan mekaanisesti, asettaa moraaliarvostelmansa kysymyksen muodossa: "Onko oppiminen siis välttämättä aina niin hyvä asia, ainakaan oppimisen seuraukset?" (Jarvis 1997, 16), ja viittaa lasten kokemiin eron tuskaan ja yksinhuoltajuuden kärsimyksiin perustellakseen väitteensä lapsen parhaalla. Viis siitä miten sinulla tai meillä menee kunhan vain lapsen asiat ovat kunnossa, sanoo Jarvisin perhekeskeinen moraali. 
Voi olla, että esimerkki on Jarvisille henkilökohtaisesti tärkeä. Tätä ei tietenkään voi kuin arvuutella. Mutta esimerkki on aivan liian tärkeä jätettäväksi tähän. Suomessahan avioerot kuuluvat nykyään aivan tavalliseen arkipäivään. Tästäkin syystä Jarvisin esittämä ongelma kuuluisi aikuiskasvatustieteen keskiöön, vaikka kirkko ja oikeisto tietysti kantavat asiasta yhteistä huolta samalla, kun voivottelevat hyvinvointivaltion johtavan kansalaisten moraalin rappioon.

Juuri tällä kohdalla Jarvisin tekstistä paistaa myös teoreettinen individualismi, vaikka puhe onkin oppimisen sosiaalisista ulottuvuuksista ellei peräti oppimisen sosiologiasta: "Oppiminen on yksilöllinen prosessi" (Jarvis 1997, 16) on ongelmallinen väite. Entä jos yksilöllinen oppiminen tapahtuukin aina sosiaalisen sfäärin kautta? Voiko oppimista enää silloin pitää yksilöllisenä prosessina? Mutta avioerot tai teoreettinen individualismi eivät ole ainoita eivätkä keskeisiäkään syitä parisuhde-esimerkin tärkeyteen.

\section{Perhe-eetos luonnonjärjestyksenä}

Keskeistä Jarvisin esimerkissä oppimisen paradoksista on sen sijaan se, että siihen on kirjoitettu sisään eräitä aikakautemme keskeisiä sosiaalista järjestystä ja yhteiskunnallista valtaa koskevia oletuksia, joista on runsaasti edelleen kehiteltävää muillekin kuin asiasta innostuneelle aikuiskasvatuksen opiskelijalle.

On kysyttävä yhteiskunnallisen ongelman alkuperää: millaiselle yhteiskunnalle parisuhteessa erilleen kasvaminen on ongelma? Vastaus on ilmeinen: asia on ongelma yhteiskunnalle, jossa tärkein yhdessäolon ja seksuaalisuuden toteutumisen tapa on vastakkaisten sukupuolten muodostama perhe.

Parisuhteelle perustuva perhe on modernin yhteiskunnan tärkein peruspilari, modernin sosiaalisen järjestyksen kitti. Tämän todisti jo Edvard Westermarck viktorianaikaisessa tutkimuksessaan avioliiton historiasta. Sen mukaan nimenomaan yksiavioisuus perhesuhteena on ylivertainen ja luonnonjärjestyksen mukainen elämänmalli.

Tämä perhe-eetos - tai lisääntymismoraali (Varto 1997) - on sitten säilynyt suhteellisen itsestään selvänä yhdyselämän järjestyksenä viimeiset 150 vuotta. Sukupuolimoraali on pitkään ollut epäkysymys, kaikki on ollut kovin selvää tällä alueella. Tässä ei ole ollut mitään paradoksaalista, tähän luonnonjärjestykseen sukupolvet on kasvatettu, minä muiden mukana. Tämän näkemyksen puitteissa ei ole ollut tilaa avoimelle vaihtelulle, sukupuoliroolit ovat olleet selvät, homoseksuaali säätieteilijä mediassa on ollut kuin luonnonoikku sirkuksessa.

Tästä näkemyksestä minäkin luin Jarviksen esimerkkiä itsestäänselvästi, ajattelematta, niinhän se on, niin sen täytyy olla. Yhteiskunnallinen ongelma tästä syntyy silloin, kun huomataan maailmanjärjestyksen tai ihmisten tapojen muuttuneen siihen mittaan, että vanhat normit ja normaaliuden mitat eivät enää päde. Avioerotilastot ovat tästä muutoksesta tietenkin eräs, mutta vain yksi empiirinen ilmaus. Laajemmin kysymys on koko senaikaisen sosiaalisen järjestyksen murroksesta, jossa perheja avioliitto syntyivät ihmisonnen ideaaleiksi. Tällaiselle ymmärrykselle pari- ja perhesuhteista erilleen kasvaminen on yhteiskunnallinen ongelma, vaikka jokseenkin aina myös henkilökohtainen tragedia.

\section{Henkilökohtainen tragedia}

Aina ei välttämättä ole niin, että uudet haasteet virittäisivät oppimista. Voi käydä niinkin, että uusi tukahduttaa omaehtoisen kasvun, että psyykkinen ja sosiaalinen kasvaminen tyrehtyy ulkoisten oppimispaineiden alle. Aikuiskasvatustieteen alueella jatkuvan oppimisen harhaan on helppo mennä, kun oppimisesta on alettu puhua laajana käsitteenä, joka kattaa lähes kaiken käsitetyn inhimillisen toiminnan. Erityisesti näköharha on olemassa työelämäkoulutuksen tutkimuksessa, jolla on keskeinen osa niin alueemme empiirisessa kuin teoreettisessa tutkimuksessa. Työelämässähän ihmistä voidaan oppimisen nimissä rankaista miltei rajattomiin kaikki se kouluttautumisen pakko osoittamaan, että olet kunnollinen! 
Täytyy kuitenkin muistaa, että ihmisen tajunnassa on kerrostumia, jotka eivät ehkä koskaan kohoa tietoisen reflektoinnin eivätkä oppimisen piiriin. (On makuasia halutaanko näistä kerrostumista käyttää nimitystä tiedostamaton oppiminen). Toiseksi on epäilyttävää edes sanomattomasti väittää, ettei työn ulkopuolella, elämän muilla alueilla kodissa, lähipiirissä, arjessa, voisi tapahtua kasvamista. Juuri niissä voi oppia paljon enemmän enemmästä ja tärkeämpää tärkeämmästä; niissä voi etsiä kohtaa aktiiviselle levolle, josta kaikki uutta luova syntyy.

Christer Kihlman (1971, 167-168) kirjoittaa samasta kuin Jarvis, mutta kokolailla erilaisin painotuksin. Nyt näkökulma ei suodatu työn kautta, vaan menee parisuhteen sisään, käsittelee sen mutkikkaiden merkitysten leikkiä. Kihlmanin kohtauksessa Maisa on alkuun "nukke-kaappikokoa, niin pieni ettei kukaan oikeastaan ottanut häntä todesta." Masa sen sijaan "suuri, lahjakas, lupaava. Masaan olivat katseet ensi sijassa kohdistettu, Masaan oli ensi kädessä toiveet kiinnitetty." Vuosien kuluessa Maisa alkaa kasvaa. Myös Masa kasvaa, mutta ei yhtä nopeasti eikä huomiotaherättävästi. Siinä missä Maisasta kasvaa ajanoloon itsenäisempi, riippumattomampi ja aikuisempi kuin ennen, siinä Masa vajoaa uuteen infantiiliuteen. Lopulta edessä on paradoksi: “mitä enemmän he tällä tavoin lähenevät toisiaan, siis mitä selvemmin heidän keskinäinen tasavertaisuutensa korostuu, sitä mahdottomammaksi käy heidän avioliittonsa, sitä pirstoutuneemmaksi, sitä lopullisemmin sovittamattomien ristiriitojen repimäksi."

Kihlmanilla on kysymys samasta parisuhteen ja erilleen kasvamisen dynamiikasta kuin Jarvisilla, mutta paljon hienosyisemmin ja paradoksaalisemmin. Kihlman tavoittaa mutkikkaiden paritunteiden leikistä jotain sellaista, joka Jarvisin suoraviivaisuudessa jää tavoittamatta - vaikka kohtausten lopputulos aavisteleekin samaa.

\section{Biovalta roihuaa}

Parisuhteen paradoksi toimii sellaisen valta- käsityksen näyttämönä, jota Michel Foucault analysoi biovallan käsitteellä. Biovalta on hallinnan teknologia, joka tekee tieto-valta-muodostumista keinon muunnella inhimillistä elämää ja tuo kaikki elämänalueet laskelmoinnin piiriin (Foucault 1990, 143). Kun ihminen ei teollistumisen jälkeen enää ollut sidottu maahan, tuli hänestä sielullaan sidottu sosiaalisiin, emotionaalisiin ja seksuaalisiin siteisiin, lyhyesti: biovallan läpäisemään pari- ja perhesuhteeseen.

Biovalta näyttäytyy täten hyvää tarkoittavana, suojelevana ja itsestäänselvänä, ja siten tehokkaana, sieluun tunkeutuvana (sisältäpäin ohjaavana) sosiaalisen kontrollin muotona (Oksala 1997, 171; biovallasta ks. myös Hänninen \& Karjalainen 1996).

Sukupuolimoraalin kysymyksiä ja niin ollen parisuhde-esimerkin ilmiötä motivoi sukupuolisuus: halu, puute, kaipaus ja lihan himo. Seksuaalisuus on monimutkainen ja -ulottuvuuksinen - kokemuksellinen ja ideologinen konstruktio, joka on historiallisesti helpottanut em. viettivoimien ohjailua ja säätelyä (Oksala 1997, 170). Kun näille asetetaan normit, siis määritetään se mikä on normaalia, tulee määritetyksi myös epänormaali, perverssi, patologinen. Kun normaali asettaa puitteen, on puitteesta jatkuvasti puhuttava ja uusinnettava se puhein. Viimeisten kahden sadan vuoden aikana seksuaalisuudesta on puhuttu taukoamatta, enemmän kuin koskaan ennen, ja se on disiplinoitu akateemisiksi tutkimusalueiksi. Tunnustuksen perinne on siirtynyt kirkollisesta perinteestä seksiin, eletty aikakausi on ollut lihan tunnustusten aikaa.

Uusi naistutkimus tai postfeminismi on jo pitkään purkanut jakoa biologiseen (sex) ja sosiaaliseen (gender) sukupuoleen. Kun sukupuolet on purettu, on samalla mennyt myös tiukka sukupuolien erottaminen toisistaan. Ollaan ehkä palaamassa antiikin ajatukseen yhdestä kokonaisuudesta, ihmisen puolikkaista, joilla Harvan $(1980,88)$ sanoin on olemassa "biseksuaalinen potenssi." Biseksuaalisen potenssin tunnustaminen keinona rikkoa normaalin kaavaa saattaa tulla kuin taivaan lahjana yhteiskunnalliseen tilanteeseen, jossa mitkään muutkaan totutut itsestäänselvyydet - hyvinvointi- 
valtio, ydinperhe, 8 tunnin työpaikka, leiväntuojan ja sen leipojan sukupuoli - eivät pidä kutiaan.

\section{Repressiosta}

\section{seksuaalisuuden säätelyyn}

Jarvisin oppimisen paradoksista käyttämän esimerkin keskeisin ongelma on ehkä kuitenkin se, että siinä esitetään eräs historiallinen asiantila ilman, että tätä historiallisuutta todettaisiin missään. Tällä tavoin esimerkistä tulee universalia, normi ja itsestäänselvyys.

Perhe- ja parisuhteen ongelmaan on kuitenkin kirjallisuudessa annettu kaksi toisistaan poikkeavaa vastausta. Ensinnäkin sitä on lähestytty repressiohypoteesiksi kutsutulla ajatusrakennelmalla. Hypoteesi tuli tunnetuksi ja suosituksi ajattelumalliksi vuoden 1968 jälkeen, kun seksuaalisen vapautumisen ideat levisivät radikalismin aallon mukana kaikissa länsimaissa.

Repressiohypoteesin ydin kiteytyy André Giden tunnettuun huutoon: "Perheet, teitä minä vihaan!" Ajatus on tietenkin siinä, että siinä missä avioliitto porvarillisen moraalin pyhättönä tukahduttaa ja rankaisee, siinä tästä pakkopaidasta vapautuminen johtaa spontaaniin ja vapaaseen aisti-ilojen täyttämään elämään, ihmisenäolemisen lihallisten täyteyksien löytämiseen.

Repressiohypoteesin ongelma on se, että siinä oletetaan turhan höllin perustein perheen ja parisuhteen alistavan ja latistavan seksuaalisuuden pelkäksi tuotannontekijäksi ja osaksi yhteisön uusintamisrituaalia. Lisäksi oletetaan, että vapaa aistillisuus löytyy pakottamalla, kuten Gide-tuntija Göran Schildt $(1995,101)$ ongelman muotoilee: “On vaikeaa olla tietoisesti tiedoton, olla tahallaan spontaani."

Toiseksi repressiohypoteesi on pyritty ylittämään rakentamalla sen rinnalle tarkempi analyysi seksuaalisuudesta ja sen merkityksestä hallitsemisen välineenä.

Ihmisten hallitseminen muodostui 1400-luvulta alkaen keskeiseksi yhteiskunnalliseksi kysymykseksi ja 1700-luvulla ihmisistä "väestönä” tuli taloudellinen ja poliittinen ongelma. Ihmisten väestöllistä seksuaalisuutta ryhdyttiin säätelemään esim. syntyvyyden, avioitumisiän, legitiimin synnyttämisen, seksuaalisten suhteiden laadun ja tiheyden, hedelmällisyyden, sterilisaation, naimattomuuden seurausten ja ehkäisyn vaikutusten avulla (Foucault 1990, 2526). Siis kaikkien sellaisten praktiikoiden avulla, jotka nykyään ovat arkipäivää ja otetaan kyselemättä.

Tekstissään "Biopolitiikan synty” Foucault (1997, 74-75) liittää seksuaalisten käytäntöjen hallinnan ja väestön ongelman liberalismin syntyyn. Liberalismilla tarkoitetaan hallinnon toiminnan ja rationalisuuden tapaa ja periaatteita. Sisäinen yhteys liberalismin ja biovallan välillä syntyy jälkimmäisen pyrkimyksestä irtautua liiasta hallitsemisesta (ja samalla totella "the internal rule of maximum economy"). Liberalistien asettama kysymys: miksi ylipäätään pitää hallita?, saa vastineensa biovallan näkymättömyydessä, tunkeutumisessa ihmisen sieluun. Erityisesti uusliberalismin tapa ujuttaa markkinoiden rationaalisuus sellaisillekin elämänalueille, jotka eivät ensi sijassa ole taloudellisia, on analoginen biovallan toiminnalle.

\section{Kuka kasvaa, kuka oppii?}

Palatakseni lähtökohtaan, kysymys lienee siitä, millaisesta näkökulmasta biovallan läpäisemiä pari- ja yhteiskunnallisia suhteita halutaan tarkastella. Jarvisin näkökulma on jokseenkin historiaton tai yhdellä tavalla historiallinen, ja selvästi WASPin, jota hallitsee patriarkaalinen työ- ja perhekeskeisyys. Patriarkaatilla en viittaa isänvaltaan, sehän olisi hassua nykyisessä tilanteessa, vaan yleensä elämäntapaan, joka uusintaa ja pyhittää lisääntymismoraalin: avioliiton, uran, lastenteon ja -kasvatuksen, kulutuksen ja taloudellisen yltäkylläisyyden unelmat.

Kihlmanin opastuksella jouduin työ- ja perhekeskeisen tulkinnan sijaan aivan toisenlaiseen tulkintaan, joka johdatti myös biovallan vaiheille; siihen kuinka jokainen seksuaalinenkin käytäntö on kerran syntynyt, siis historiallinen, kuinka jokaista seksuaalisuudenkin motivoimaa 
käytäntöä tarkastellaan normaalin ja epänormaalin valaistuksessa, ja kuinka näille käytännöille alunperin annetut merkitykset ovat kenties jo häipymässä.

Tajusin, ettei oppiminen jälkimoderneissa yhteiskunnissa ole vain paradoksaalista, vaan usein järkyttävää. Kysymys erilleen kasvamisesta on siten kysymys siitä miten me elämme, mitkä ovat yhteiselämämme moraaliset puitteet. Että ne ovat historiallisesti muotoutuneita ja jatkuvasti muotoutuvia, kulttuurisesti vaihtuneita ja alati vaihtelevia, sosiaalisesti uusinnettuja ja koko ajan uusinnettavissa, ja vaikeasti toisin ajateltavia, muutettavia saati elettäviä.

Tämän me olemme alkaneet unohtaa: että elämää voi elää monella tavalla, että vaihtoehtoja tulee luoda nykyisyyden pakottavuuden rinnalle. Tämä on myös aikuiskasvatuksen tehtävä.

\section{Lähteet}

FOUCAULT, M. (1990) The history of sexuality Vol. 1. New York: Vintage Books.

FOUCAULT, M. (1997) Ethics. Subjectivity and truth. The essential works of Michel Foucault Vol. 1. New York: The Free Press.

HARVA, U. (1980) Moraalin ongelmia. 4. p. Keuruu: Otava.

HEISKALA, R. (1996) Kobti keinotekoista ybteiskuntaa. Tampere: Gaudeamus.

HÄNNINEN, S. \& KARJALAINEN, J. (toim.) (1996) Biovallan kysymyksiä. Tampere: Gaudeamus.

JARVIS, P. (1993) Oppimisen paradokseja myöhäismodernissa. Aikuiskasvatus 13 (3), 181-187.

JARVIS, P. (1997) Oppimisen paradokseja. Aikuiskasvatus 17 (1), 12-17.

KIHLMAN, C. (1971) Ibminen joka järkkyi. Suom. Pentti Saaritsa. Helsinki: Tammi.

OKSALA, J. (1997) Foucault ja feminismi. Teoksessa Heinämaa, S., Reuter, M. \& Saarikangas, K. (toim.) Ruumiin kuvia. Tampere: Gaudeamus, 168-190.

SCHILDT, G. (1995) Lainasiivin. Nuoruudenmuistelmat. Keuruu: Otava.

VARTO, J. (1997) Vastuu aidsin aikakaudella. niin \& näin 4 (1), 54-57. 